\title{
Effects of terrestrial runoff on the coral communities in Santiago Bay, Colima, Mexican Pacific Coast
}

\author{
Marco Agustín Liñán-Cabello ${ }^{1 *}$, Aramis Olivos-Ortiz², Sonia Quijano- Scheggia², Daniela Muñiz \\ Anguiano $^{1}$, María Luisa Reséndiz-Flores ${ }^{1} \&$ Christian D. Ortega-Ortiz ${ }^{1}$ \\ 1. Acuacultura/Biotecnología, FACIMAR. Universidad de Colima, Colima. Km 19.5 Carretera Manzanillo-Barra de \\ Navidad, Manzanillo, Colima, México. CP 28868; linanm@ucol.mx, danny.muang@gmail.com, \\ mresendis@ucol.mx, chistian_ortega@ucol.mx \\ 2. Centro Universitario de Investigaciones Oceanológicas (CEUNIVO). Universidad de Colima. Km 19.5 Carretera \\ Manzanillo-Barra de Navidad, Manzanillo, Colima, México; aolivos@ucol.mx, quijano@ucol.mx \\ * Correspondence
}

Received 17-XI-2015. Corrected 12-IV-2016. Accepted 20-V-2016.

\begin{abstract}
Coral reef ecosystems are under stress of different origins, from factors including sedimentation, fragmentation, overfishing, and tourism, depending on their geographical location, depth, and proximity to recreation areas. In this study of Juluapan Lagoon, we examined the relationship between various water-quality attributes and the status indicators of the coral community at La Boquita reef. During 2011 (12 months of sampling), six monitoring stations in the Juluapan lagoon were established in order to observe the gradient of the distribution of the physicochemical parameters: three stations on the upper part, or BI, (S4 to S6) and three more in the lower part, or BII, (S1 to S3). A control station (CS) was located in the coral reef close to the lagoon channel, and where dissolved inorganic nutrients and cellular carbon content were determined. Additionally, we considered the monitoring of three of the eight largest coral structures/headlands of this community: the first was the station closest to the channel communicating with Juluapan lagoon $(\mathrm{C} 1)$, the second was in the intermediate region with respect to that lagoon $(\mathrm{C} 2)$, and the third was farthest from the channel (C3). Three line intercept transects (LIT) $30 \mathrm{~m}$ in length and perpendicular to the coast provenance were established in each station, and the parameters indicative of the status of corals were evaluated in an area of $60 \mathrm{~m}^{2}$ on each transect $\left(180 \mathrm{~m}^{2}\right.$ by the station). Turbidity, evidence of fishing, signs of settling, algal coverage, abundance of fish, rate of sediment, and coral health records (as for CoralWach chart) were determined in situ and from digital photographs and videos. Considering various community status indicators used in the reef area, we could recognize a state of general deterioration, which was reflected in the loss of $17 \%$ of coral coverage. The main anthropogenic disturbances in adjacent areas to La Boquita reef included wastewater discharges into the lagoon, tourist developments in the coastal zone, deforestation and erosion resulting from inappropriate development, and the runoff of nutrients from agricultural lands nearby the lagoon. All these significantly contributed to the nutrient-enriched waters of the lagoon, especially in summer, with negative effects on the coral community. Continued exposure to these factors, coupled with the lack of control over other anthropogenic components, has promoted the maintenance of a chronic stress state in the studied coral community. Our findings highlight the need for the development of appropriate coastal management and conservation policies for the coral reefs of the Mexican Pacific Coast. Rev. Biol. Trop. 64 (3): 1185-1200. Epub 2016 September 01.
\end{abstract}

Key words: coral environments, loss of coverage, anthropogenic impacts, bioerosion, eutrophication, Pocillopora.

Coral reefs are complex marine ecosystems whose health relies on stable environmental conditions, though parallel to, regional coastal economies in many countries depend on coral reef ecosystems because they provide habitat for many marine species of economic and ecological importance (Falkowski, Jokiel, \& Kinzie, 1990; Cesar, Burke, \& Pet-Soede, 2003). For the last several decades, however, coral communities have been severely 
threatened by changes related to their environment, the effects of which have been further exacerbated by anthropogenic activities (Maina, McClanahan,Venus, Ateweberhan, \& Madin, 2011). Coral communities are vulnerable to the effects of storms and hurricanes, which can cause massive mortality, because of the intense wave energy associated with these events, and the sediment and nutrient inputs surplus resulting from the accompanying heavy rainfall (Crabbe, Walker, \& Stephenson, 2008). Other environmental factors, such high levels of solar radiation and thermal anomalies, may encourage disease propagation, resulting in coverage loss (Maina et al., 2011). Moreover, corals respond to adverse thermal conditions by expelling their algal symbionts, which results in so-called coral bleaching (Lesser, 2006; Cunning \& Baker, 2013). Though some of the above "natural" threats to coral may be increased by some of the anthropocentric threats described below: coral communities and its fauna (e.g. fishes, invertebrates, among others) are also sensitive to several factors resulting from the development of coastal areas, including those arising from unregulated coastal construction, urban development, deforestation, chemical contamination (i.e., runoff from pesticides, herbicides and fertilizers), overfishing, and destructive fishing methods, that in particular, or in synergistic association, may affect the stability of coral communities (Buddemeier, Kleypas, \& Aronson, 2004; Costa, Nimmo, \& Attrill, 2008; Hilmi, Safa, \& Reynaud, 2012).

The role of nutrient enrichment in the degradation of coral reef communities is not well-studied for the Mexico Pacific Coast. Numerous studies have suggested that an increase in nutrient concentration supports a higher proportion of macroalgae in coral communities (Delgado \& Lapointe, 1994; Adey, 1998), though this conclusion could not be confirmed in other studies (Larkum \& Koop, 1997; Koop et al., 2001). However, according to some reports (Fabricius, 2005; Fabricius et al., 2013), both, coastal communities and marine coral reefs, have increased levels of nutrients, sediment and pollutants originating from the continent. Terrestrial runoff is therefore a growing concern for most of the 104 nations endowed with coral reefs (Spalding, Ravilious, \& Green, 2001; Fabricius, 2005).

Of particular concern are the synergistic effects of the above-mentioned factors, in decreasing the resilience of coastal coral communities to climatic impacts (Micheli et al., 2012). Although it is known that, the dynamics to understand multiple stressor interactions can be highly complex in marine systems (Crain, Kroeker, \& Halpern, 2008). Some authors have recognized that if the intensity of stress effects overcomes the coral reefs recovery ability, the inevitable result is a progressive loss of coral cover (Koop et al., 2001; Cesar et al., 2003; Lirman \& Fong, 2007).

In this study, we examined the relationship between various water quality indicators and the status of the coral community known as La Boquita, in Juluapan Lagoon, Colima, México. Our results improved our understanding of the processes that alter the ecological balance of coral communities, especially, those associated with stress and the loss of coverage due to terrestrial runoff. We may recognize, if the conditions of increased terrestrial runoff throughout the year, have a more significant effect on the state of deterioration of La Boquita coral community.

\section{MATERIALS AND METHODS}

Study site: Santiago Bay is located in Pacific central zone of Colima, México. The coral community known as La Boquita is situated in the Western part of the Bay at $19^{\circ} 12^{\prime} 25^{\prime \prime}$ $\mathrm{N}-104^{\circ} 28^{\prime} 52^{\prime \prime} \mathrm{W}$ (Fig. 1). The coral patches comprising this community cover an area of $3876.2 \mathrm{~m}^{2}$, extending from the surface to a depth of $3.5 \mathrm{~m}$ (Liñán-Cabello et al., 2008). The system includes the Juluapan Lagoon, which is connected to Santiago Bay through an artificial entrance channel built in 2003 that is $20 \mathrm{~m}$ wide, $75 \mathrm{~m}$ long, and between 0.3 and $0.8 \mathrm{~m}$ deep. The lagoon has an approximate area of 98 ha and is divided into two upper 

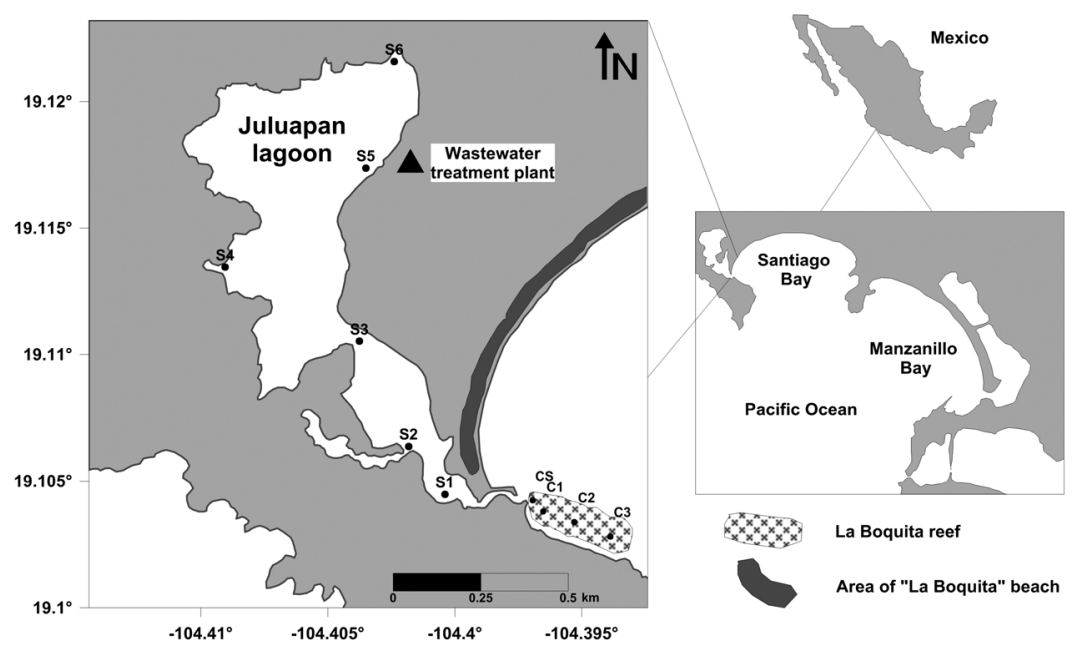

Fig. 1. Location of the La Boquita coral community on the coast of Colima, Mexico. S1-S6 mark the location of the sampling stations (temperature, salinity, nutrients, phytoplankton) within the Juluapan lagoon and the control station (CS) in 2011. C1, C2, and C3 indicate the location of the sampling stations on the coral (structure, composition, turbidity of water column, algal coverage) during September, November (2011), and January (2012).

and lower basins (BI and BII, respectively), with a major and minor axis length of $2 \mathrm{~km}$ and $1.4 \mathrm{~km}$, respectively. The two basins have a depth of $1 \mathrm{~m}$ at most sites, although some areas in the principal channel are up to $5 \mathrm{~m}$ deep; along the edges, the water is as shallow as $20 \mathrm{~cm}$; its dynamics are dominated by tidal influence and forcing local winds (GaviñoRodríguez et al., 2011). Juluapan Lagoon is separated from Manzanillo Bay by a sand bar of $500 \mathrm{~m}$ long (La Boquita beach), on which tourist activities including restaurant service is developed. This lagoon receives the seasonal waters of the Miramar stream, during the rainy season, which occurs in summer from June to October (range: $600-1300 \mathrm{~mm}$ ), so the climate in the region is warm and sub-humid (range $18-28^{\circ} \mathrm{C}$ ), (INEGI, 2009). La Boquita coral reef is under a variety of pressures related to human visitors due to its close proximity to recreational areas (Liñán-Cabello, HernándezMedina, Florián-Álvarez, \& Mena-Herrera, 2008). However, the main impacts are thought to be the influx of warm water. Previous reports in the study zone have found wide fluctuations in salinity and superficial temperature (OlivosOrtiz et al., 2008).
Water quality: During 2011 (12 twelve months of sampling), six monitoring stations inside of the Juluapan lagoon were established in order to observe the gradient of the distribution of the physicochemical parameters: three stations on the upper part, or BI, (S4 to S6) and three more in the lower part, or BII, (S1 to $\mathrm{S} 3$ ); a control station (CS) was located in the coral reef at a site close to the lagoon channel (Fig. 1). Between January and December of 2011, samples were monthly taken at the surface $(20 \mathrm{~cm}$ deep) inside the lagoon, and at a depth of $1.0 \mathrm{~m}$ in the marine zone. Temperature and salinity were determined in situ with the Geoscientific field multi-parameter instrument YSI85 (accuracy \pm 0.1 ). To determine the concentration of dissolved inorganic nutrients $\left(\mathrm{NO}_{2}^{-}+\mathrm{NO}_{3}^{-}, \mathrm{NH}_{4}^{+}, \mathrm{PO}_{4}{ }^{3-}\right.$ and $\left.\mathrm{SiO}_{2}\right), 200 \mathrm{~mL}$ samples were collected using a segmented flow autoanalyzer (Skalar SanPlus II) according to the methods of Strickland and Parsons (1972) and Grasshoff, Ehrhardt and Kremling (1999). From each sample, three aliquots of $50 \mathrm{~mL}$ were taken to have replicates in order to assess the reliability of the method. The stoichiometric ratio of nutrients in the water was evaluated 
according to the method of Justic, Rabalais, Turner and Dortch (1995).

Phytoplankton: The phytoplankton abundance influences the availability of light that corals can use, and therefore it is an important parameter to determine. At the same locations described above, samples were collected in 1-liter bottles and fixed with Lugol. Subsamples $(50 \mathrm{~mL})$ were allowed to settle in counting chambers for $24 \mathrm{~h}$, and the phytoplankton in an appropriate field or transect, was subsequently enumerated and taxonomically identified using a Motic AE31 inverted bright-field microscope at a $200-400 \times$ magnification according to the method of Throndsen (1995). The limit of detection of the Utermöhl method is 20 cells/L (Utermöhl, 1931). Cell dimensions were measured using Motic Images Plus, Version 2.0. At least 25 randomly selected cells were analyzed for each of the most abundant species, as well as $10-15$ cells for all other determinations. Cell biovolumes were calculated based on the approximation to the nearest geometric shape, as proposed by Hillebrand, Dürselen, Kirschtel, Pollingher and Zohary (1999). Cell carbon (C) content was estimated with two carbon-to-volume ratios, one for diatoms and one for all other algal groups (Menden-Deuer \& Lessard, 2000).

Primary productivity constituted an indicator of phytoplankton abundance, but additionally, during 2012, we monitored primary productivity at three surface stations in the La Boquita coral reef, which were located close to the lagoon channel entrance $(\mathrm{C} 1)$, at moderate (C2) and large (C3) distances from it (Fig. 1). Water samples were fixed immediately after collection with Lugol solution.

Status of the coral community: The biological information was collected in each of the three stations and three monthly samplings (September and November 2011 and January 2012) of the reef referred to above, we consider for sampling of three of the eight largest coral structures/headlands of this community, which are similar in terms of composition and depth
(Liñan-Cabello et al., 2008; Reyes-Bonilla et al., 2013): the first was the closest to the channel communicating with Juluapan lagoon, whose extension is $\sim 489 \mathrm{~m}^{2}\left(\mathrm{C}_{1}\right)$; the second was in the middle of an area of approximately $\sim 746 \mathrm{~m}^{2}\left(\mathrm{C}_{2}\right)$; and the third was the farthest intercom, with an area of $\sim 334 \mathrm{~m}^{2}\left(\mathrm{C}_{3}\right)$. Three line intercept transects (LIT), $30 \mathrm{~m}$ length, and perpendicular to the coast were established in each station (GCRMN Hill et al., 2004). The parameters indicative of status of coral community were evaluated covering an area of 60 $\mathrm{m}^{2}$ around each transect $\left(180 \mathrm{~m}^{2}\right.$ by the station, see below). Considering the low depth associated with the three stations (surface to $3.5 \mathrm{~m}$ ), all underwater surveys were conducted under high-tide conditions (height: $75 \mathrm{~cm}$ ). During September, November 2011 and January 2012, digital photographs and videos were taken at each sampling site, using a Canon PowerShot S80 camera and a JVC (model 601244) digital video camera equipped with an underwater housing, respectively. Fish abundance was evaluated by using a stationary visual census (Hill \& Wilkinson, 2004). Turbidity was measured at the beginning, middle, and end of the LIT in each coral structures with a Secchi disk; evidence of fishing activities (i.e. objects fishing by transect), signs of settling ( $\%$ coral covered by sediment), and algal coverage (\%) were measured via the visually, as this is the standard method recommended by the Global Coral Reef Monitoring Network (GCRMN) (Hill \& Wilkinson, 2004).

In addition, we used the CoralWatch global monitoring program to evaluate the health status of the coral community (Siebeck, Marshall, Klüter, \& Hoegh-Guldberg, 2006). This widely used method was previously applied in the study area to evaluate the status of coral populations of Pocillopora spp. (Liñán-Cabello et al., 2011). In the present work, coral color was evaluated in situ and compared to the CoralWatch chart, which identifies four basic coral morphotypes that facilitate the evaluation of coral hue (four series, B-E), each divided into six color fields (1-6), ranging from near-white to dark brown. Each color square on the chart 
was related to the density of zooxanthellae, an important indicator of coral health and thus the health of the entire reef (Siebeck et al., 2006), according to previous studies that have tested density of symbiont vs color in the Eastern Pacific (Liñán-Cabello et al., 2011; Marshall, Kleine, \& Dean, 2012).

Finally, sedimentation on coral structures was examined at each sampling station by two placing settlers with a surface area of $200 \mathrm{~cm}^{2}$, at a depth range of 0.70-1.50 m (Liñán-Cabello et al., 2011). These collectors were placed at each transect area for periods of 15 days to a month, from September 2011 to January 2012. The samples were dried and sieved, and the gravel, sand, and silt components were measured. The ratios of these sedimentary components were determined, and the sum of their weights was used to calculate the sedimentation rate ( $\mathrm{g} /$ month). This is a method commonly used to study coral sediment composition (GCRMN) (Hill et al., 2004).

Normality and homogeneity were evaluated using Kolmogorov-Smirnov and Bartlett tests, respectively (Zar, 1994). One-and twoway ANOVAs were employed to evaluate the differences between each parameter, versus each station through the period, and employing subsequent Tukey test with a 0.05 significance level, using the Statistica (Version 6.0). The limit for rejection or acceptance was $\alpha=0.05$.

\section{RESULTS}

Water quality: Salinity in both basins remained around 33.5 PSU until June (Fig. 2A and Fig. 2B). From July onward, large variations were detected, in this month a minimum (26.4 PSU) and a maximum (27.2 PSU) was detected in BI (Fig. 2A); also in July in BII, the salinity had a minimum of 34.1 and a maximum of 34.7 PSU. In October, the minimum salinity (1.8 PSU) of the entire period was detected in BI, while in BII, it was 7.6 PSU. In CS (Fig. 2C), the average salinity was 33.2 PSU for almost all months, except in September and October, when the minimum (28.8 PSU) was detected. In October, CS and S3 (BI) showed significant differences from the other stations and months $(\mathrm{P}<0.05)$.

In general, the water temperature at the six sampling stations inside Juluapan Lagoon, exhibited the expected seasonal variations, with higher temperatures in summer (maximum in August, BI: $33.5^{\circ} \mathrm{C}$ ) and lower temperatures in winter (minimum in January, BII: $24.0^{\circ} \mathrm{C}$, Fig. 2D). Also a general gradient consisting of higher temperatures in the inner part of lagoon (BI: S4-S6), that decreased towards the lower part (BII: S1-S3) and reached their lowest at the CS (Fig. 2D). Temperatures at $\mathrm{CS}$ reaching a maximum of $31.1^{\circ} \mathrm{C}$ in August and a minimum of $22.8^{\circ} \mathrm{C}$ in March (Fig. 2D). Significant differences were detected only in temperatures between CS and the average of the BI (two-way ANOVA, by season and station, $\mathrm{P}<0.05)$ between summer and winter.

The average nutrient concentration at BI or the upper part of the lagoon, showed the higher concentrations of nutrients and also an increasing tendency during and one month after the rainy season (July to November), with the maximum occurring in October $(23.4 \mu \mathrm{M}$ $\mathrm{NO}_{2}{ }^{-}+\mathrm{NO}_{3}{ }^{-}, 8.9 \mu \mathrm{M} \mathrm{NH}_{4}{ }^{+}, 14.4 \mu \mathrm{M} \mathrm{PO}_{4}{ }^{3-}$ and $54.8 \mu \mathrm{M} \mathrm{SiO}_{2} \mu \mathrm{M}$; Fig. 2A, Fig. 2E, Fig. 2H). At BII or the lower part of the lagoon, the trend regarding these nutrients was the same but with lower average values at S1 (March: $6.2 \mu \mathrm{M}$ $\mathrm{NO}_{2}{ }^{-}+\mathrm{NO}_{3}{ }^{-}, 1.7 \mu \mathrm{M} \mathrm{NH}_{4}{ }^{+}, 1.2 \mu \mathrm{M} \mathrm{PO}_{4}{ }^{3-}$, and $11.8 \mu \mathrm{M} \mathrm{SiO}_{2} \mu \mathrm{M}$; Fig. 2B, Fig. 2F, Fig. $2 \mathrm{H}$ ). The overall nutrient concentrations throughout the year tended to be substantially higher inside the lagoon than at the CS, particularly in October during the rainy season, when the greater influence of continental runoff produced maximum concentrations $\left(10.3 \mu \mathrm{M} \mathrm{NO}_{2}{ }^{-}+\mathrm{NO}_{3}{ }^{-}, 2.2\right.$ $\mu \mathrm{M} \mathrm{NH}_{4}^{+}, 3.7 \mu \mathrm{M} \mathrm{PO}_{4}^{3-}$, and $19.2 \mu \mathrm{M} \mathrm{SiO}_{2}$; Fig. 2C, Fig. 2G, Fig. 2H); related to this, significant differences $(\mathrm{P}<0.05)$ between the values of $C S$ and the values of the upper part of the lagoon (S6-BI), were observed during all sampling period.

A stoichiometric analysis was performed in order to identify the possible alteration in the proportionality of nutrients that occur within the lagoon system, because of seasonal and 


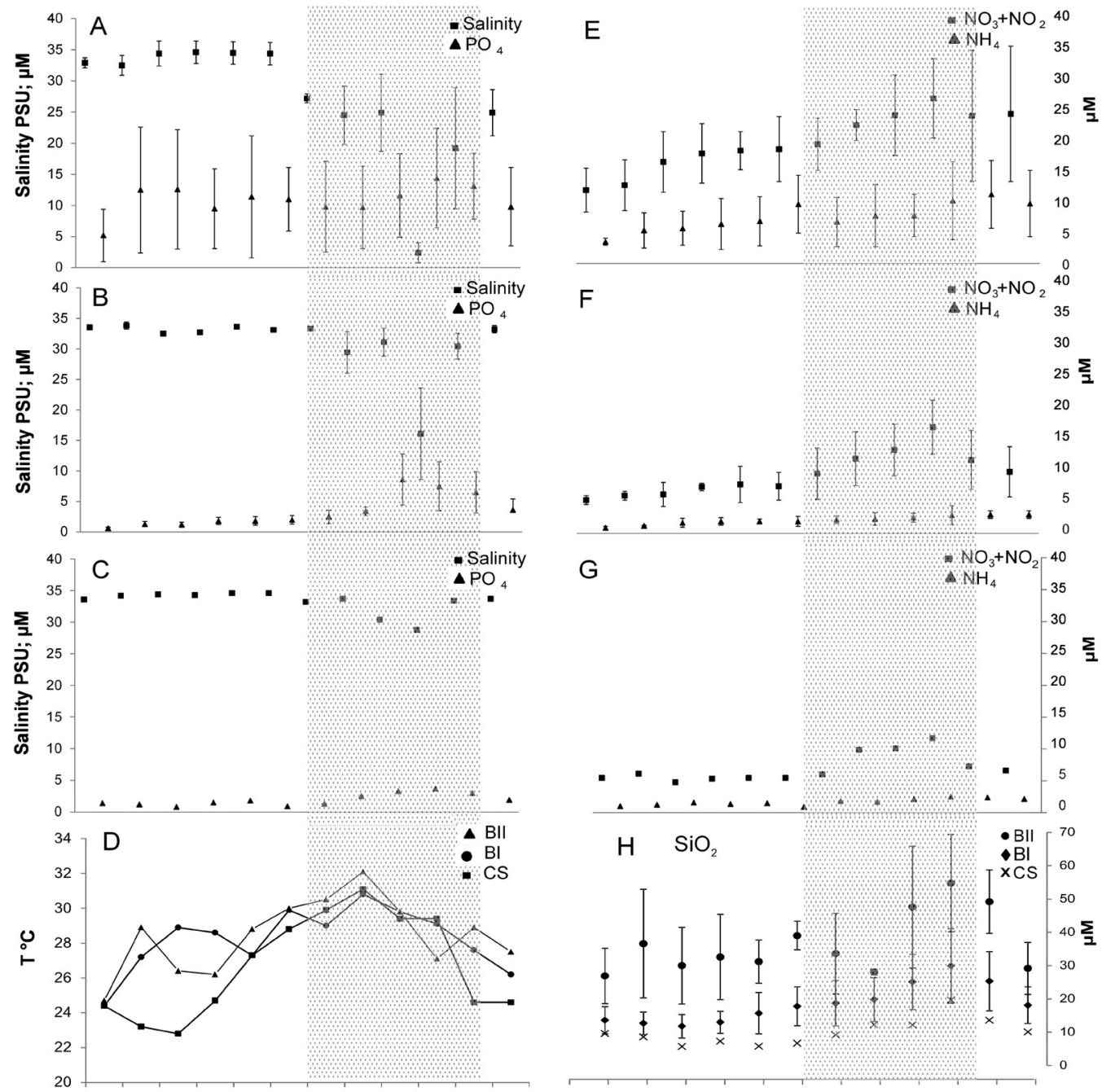

Jan Feb Mar Apr May Jun Jul Aug Sep Oct Nov Dic

Jan Feb Mar Apr May Jun Jul Aug Sep Oct Nov Dic

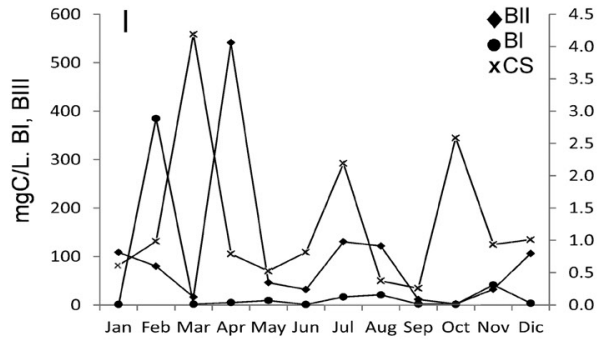

U
¿ु
है

Fig. 2. Various parameters of water quality; shaded area represents rainy season. $\boldsymbol{A}(\mathrm{BII}) \boldsymbol{\square}$ Salinity, $\boldsymbol{\Delta} \mathrm{PO}$. $\boldsymbol{B}(\mathrm{BI}) \boldsymbol{\square}$

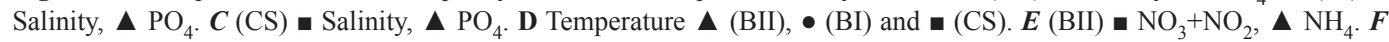
$(\mathrm{BI}) \backsim \mathrm{NO}_{3}+\mathrm{NO}_{2}, \boldsymbol{\Delta} \mathrm{NH}_{4} \cdot \boldsymbol{G}(\mathrm{CS}) \backsim \mathrm{NO}_{3}+\mathrm{NO}_{2}, \boldsymbol{\Delta} \mathrm{NH}_{4} . \boldsymbol{H} \mathrm{SiO}_{2} \bullet(\mathrm{BII}), \bullet(\mathrm{BI})$ and X (CS). I contribution of phytoplankton to Carbon $\bullet$ (BII), $\bullet(\mathrm{BI})$ and $\mathrm{X}(\mathrm{CS})$. 
continental contributions, and to determine if this may influence the adjacent coastal area where the coral reef is located. This showed no limitations regarding dissolved inorganic nutrients (DIN, P, or $\mathrm{Si}$ ) within the lagoon because the atomic ratios were $\mathrm{Si}$ :DIN $>1$ and DIN:P $>16$. By contrast, during the rainy season (July to October), results were DIN:P $=4.0$ and the DIN:Si $=0.8$, suggesting either DIN limitations or an excess of $\mathrm{P}$ and $\mathrm{Si}$ in the marine coral area.

Phytoplankton: The contribution of phytoplankton to the C content of Juluapan Lagoon during the study period was higher at BII than at $\mathrm{BI}$, in part because of the occasional phytoplankton bloom in the former. In February and April, the dinoflagellate Scrippsiella sp. was dominant in both basins but especially in BII. Peridinium quinquecorne was abundant through the year, mainly in BII. At CS, the $\mathrm{C}$ content was lower than in the lagoon, but was as high as 4.2 and $2.6 \mathrm{mgC} / \mathrm{L}$ during March and October, due to blooms of P. quinquecorne (Fig. 2I).

Primary productivity samples obtained in December 2012 at the CS in the coral reef, had high organic matter content and high cell abundance, with values ranging from $21.7 \mathrm{mgC} / \mathrm{L}$ and $1.52 \times 10^{6}$ cells $/ \mathrm{L}$ at $\mathrm{C} 3$ to
$45.9 \mathrm{mgC} / \mathrm{L}$ and $3.58 \times 10^{6}$ cells/L at $\mathrm{C} 1$ (data not showed). The optical density (measured at wavelength) values declined accordingly from $\mathrm{C} 1(0.22)$ to $\mathrm{C} 3(0.12)$.

Status of the coral community: The data obtained at each sampling station during the three samplings (September, November 2011, and January 2012) are summarized in table 1. At $\mathrm{C} 1$, in general, the live coral patch attached to the mouth of the Juluapan Lagoon, was significantly affected respect to $\mathrm{C} 3$ station $(\mathrm{P}<$ $0.05)$. In $\mathrm{C} 1$, there were also more significant values $(\mathrm{P}<0.05)$ for settling, increased turbidity, and macroalgae abundance. Additionally, abandoned fishing gear was seen at C2. Exceptionally, we observed that during low-tide conditions, turbidity restricted visibility to 18 $\mathrm{cm}$ and $80 \mathrm{~cm}$ at $\mathrm{C} 1$ and $\mathrm{C} 2$, respectively. At $\mathrm{C} 3$, regardless of the tidal conditions, visibility was unimpeded. It should be noted that $\mathrm{C} 1$ showed from 27.9 to $24.5 \%$ of sediment cover during the three sampling periods. Based on the total of indicators, we calculated a $17 \%$ loss of coral coverage.

According to our macroalgae observations at the three lagoon stations, $\mathrm{C} 1$ had the highest abundance of the genus Bossiella and other types of algae-type turf; the latter were associated with a higher abundance of coral sediments.

TABLE 1

Various indicators of population status at three locations in La Boquita reef

\begin{tabular}{|c|c|c|c|c|c|c|c|c|c|}
\hline \multirow{2}{*}{ Parameter } & \multicolumn{3}{|c|}{ September } & \multicolumn{3}{|c|}{ November } & \multicolumn{3}{|c|}{ January } \\
\hline & $\mathrm{C} 1$ & $\mathrm{C} 2$ & $\mathrm{C} 3$ & $\mathrm{C} 1$ & $\mathrm{C} 2$ & $\mathrm{C} 3$ & $\mathrm{C} 1$ & $\mathrm{C} 2$ & $\mathrm{C} 3$ \\
\hline Turbidity $(\mathrm{cm})$ & $18.4^{\mathrm{a}} \pm 21.1$ & $80.2^{b} \pm 15.7$ & $220^{\mathrm{b}} \pm 42$ & $32^{\mathrm{a}} \pm 18.4$ & $193^{b} \pm 98$ & $220^{\mathrm{b}} \pm 32$ & $37^{\mathrm{a}} \pm 52.2$ & $168^{b} \pm 54$ & $220^{\mathrm{b}} \pm 62$ \\
\hline $\begin{array}{l}\text { Abundance of algae on coral } \\
\text { (\% coral covered by algae) }\end{array}$ & $60^{\mathrm{a}} \pm 11.3$ & $19^{b} \pm 9.2$ & $22^{\mathrm{b}} \pm 11$ & $58^{\mathrm{b}} \pm 21$ & $27^{b} \pm 11$ & $29^{b} \pm 13$ & $62^{\mathrm{a}} \pm 23$ & $22^{\mathrm{b}} \pm 98$ & $11^{\mathrm{c}} \pm 2.1$ \\
\hline $\begin{array}{l}\text { Abundance offish } \\
\text { (no. fish / transect.) }\end{array}$ & $18^{\mathrm{a}} \pm 7.5$ & $22.5^{\mathrm{a}} \pm 8.91$ & $14^{\mathrm{b}} \pm 12$ & $12^{b} \pm 8.1$ & $22^{a} \pm 16$ & $12^{\mathrm{b}} \pm 7.0$ & $14^{\mathrm{b}} \pm 6.1$ & $22^{\mathrm{a}} \pm 19.1$ & $19^{\mathrm{a}} \pm 9.5$ \\
\hline Live coral (\% live coral) & $60^{\mathrm{a}} \pm 22.5$ & $92^{b} \pm 23.6$ & $97^{b} \pm 14.8$ & $66^{\mathrm{a}} \pm 0.69$ & $94^{b} \pm 13.6$ & $90^{b} \pm 26.2$ & $62^{\mathrm{a}} \pm 9.1$ & $95^{b} \pm 14.5$ & $95^{\mathrm{b}} \pm 13.4$ \\
\hline $\begin{array}{l}\text { Evidence of fishing (objects } \\
\text { fishing / transect.) }\end{array}$ & $3.0^{\mathrm{a}} \pm 0.69$ & $3.0^{\mathrm{a}} \pm 1.6$ & $2.3^{\mathrm{a}} \pm 2.8$ & $4.9^{\mathrm{a}} \pm 0.34$ & $2.5^{\mathrm{a}} \pm 0.76$ & $3.5^{\mathrm{a}} \pm 1.0$ & $2.5^{\mathrm{a}} \pm 0.85$ & $7.8^{b} \pm 1.4$ & $2.3^{\mathrm{a}} \pm 2.1$ \\
\hline $\begin{array}{l}\text { Signs of settling }(\% \text { coral } \\
\text { covered by sediment })\end{array}$ & $28^{\mathrm{a}} \pm 12.1$ & $2.2^{b} \pm 0.76$ & $1.9^{\mathrm{b}} \pm 0.27$ & $24^{\mathrm{a}} \pm 5.8$ & $2.0^{\mathrm{b}} \pm 0.68$ & $1.3^{b} \pm 0.23$ & $25^{\mathrm{b}} \pm 11.2$ & $3^{\mathrm{a}} \pm 0.69 \pm 0.59$ & $1.4^{b} \pm 0.63$ \\
\hline
\end{tabular}

Mean values with different letters are significantly different $(\mathrm{P}<0.05)$. One-way ANOVA test. Data are means \pm SD. Significant differences are shown by an asterisk $(\mathrm{P}<0.05) ; \mathrm{n}=3$ (Turbidity), $\mathrm{n}=180$ (other parameters). 


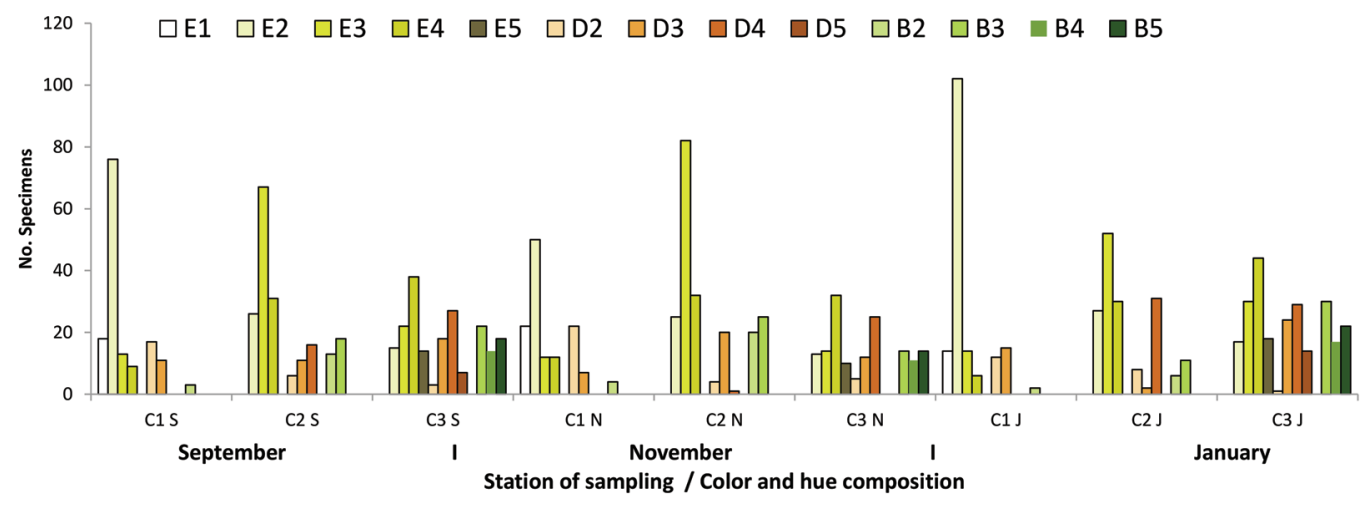

Fig. 3. Color fields and hue composition of coral morphotypes at $\mathrm{C} 1$ (next to the communication between the bay and the lagoon, $\mathrm{n}=441$ ), C2 (middle zone, $\mathrm{n}=564$ ), and C3 (opposite side, $\mathrm{n}=594$ ) during September $(\mathrm{S}) 2011$, November $(\mathrm{N})$ 2011, and January (J) 2012.

Stegastes acapulcoensis, Sufflamen verres, Thalassoma lucasanum, and Microspathodon dorsalis were most abundant fish species.

Figure 3 summarizes the results of the three sampling stations with respect to the CoralWatch classifications. $\mathrm{C} 1$ coral were characterized only by colorations 1 and 2, mostly with the hues $\mathrm{E}$ and $\mathrm{D}$. In $\mathrm{C} 2$, coral coloration was between 2 and 4, with some specimens of hue B. In C3, coral color reflected a better community status, with a larger proportion of colorations 4,5 , and 6 , within hues $\mathrm{D}$, $\mathrm{E}$, and $\mathrm{B}$. An analysis of the sediment ratio (gravel:sand:silt), at the three sites, yielded values of 1.0:0.33:0.75 at $\mathrm{C} 1,1.0: 2.0: 2.04$ at $\mathrm{C} 2$, and 1.0:2.3:1.4 at $\mathrm{C} 3$ (Fig. 4).

\section{DISCUSSION}

The temperature inside the lagoon and in the coral area showed a seasonal variation, with peaks in August and wider variations in BI than in BII and lower temperatures in the CS. The warmer temperature in the upper lagoon zone could be due to less tidal exchange and thus increased water residence time and to its shallower depth. Other studies that included the CS (Liñán-Cabello et al., 2008; Olivos-Ortiz et

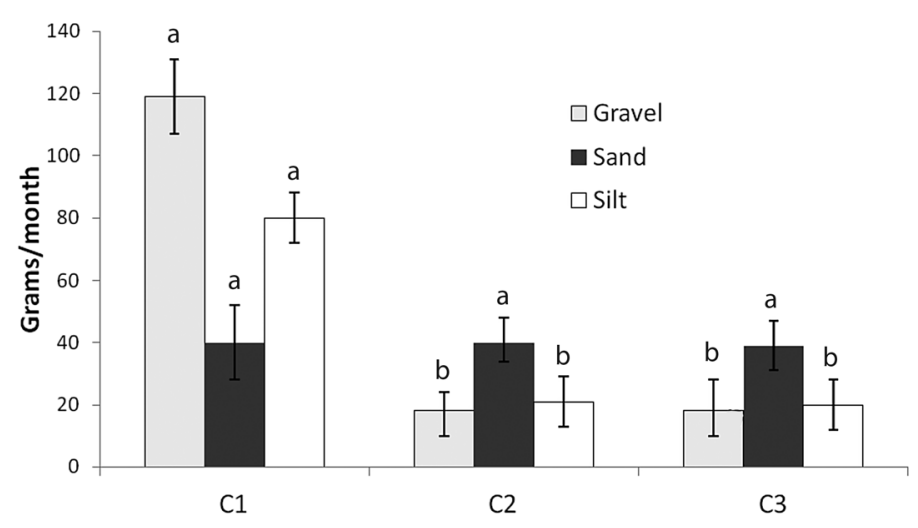

Fig. 4. Total sedimentation rate and grain type at $\mathrm{C} 1$ (next to the communication between the Bay and the lagoon), $\mathrm{C} 2$ (middle zone), and C3 (opposite side). Various symbols denote significant differences between each grain type by station of sampling $(\mathrm{P}<0.05)(n=4$, mean $\pm \mathrm{SE})$. 
al., 2008; Rivera-Vilarelle, 2011) reported the same range in surface water temperature at this site during an annual cycle; thus, the thermal influence caused by water discharge from the lagoon, can be a potential source of disturb that explain the observed decline in various population indicators of the coral community. However, temperature variation is related to salinity, because the shallow inner zones are also the sites of higher salinity, up to 34.7 PSU (BI and BII) until June. As the rain starts, the salinity in both basins decreases and the variability increases (July to November). This pattern is, in part, explained by the annual storms, which alter the salinity of the entire lagoon. Indeed, Hurricane Jova hit the study area in October, resulting in a salinity minimum of 1.0 PSU (S5) in BII and a very low salinity of 7.6 PSU in BI (S1), whereas in the CS, located on the west side of the reef and unaffected by the storm, the salinity during this same period was $28.8^{\circ} \mathrm{C}$. This recurrent pattern of intense rainfall, with as much as $400 \mathrm{~mm}$ recorded in the region (SMN, 2011), accompanied by large decreases in salinity can, through continental discharge, cause abrupt changes in salinity and thus negatively impact the coral community (Ban, Graham, \& Connolly, 2014), our results, this variable could be associated with the lack of healthy corals in the area near the Juluapan Lagoon effluent. Related to this, it was considered that the corals are osmo-conformers, gaining water and becoming iso-osmotic with their surroundings when exposed to hyposaline conditions (Titlyanov et al., 2000). It is for this reason that in a hypotonic medium, different disturbances at the cellular level, including damage to mitochondria, have been reported (Moyes, Moon, \& Ballantyne, 1986; Martínez, Pardo, Flores-Herrera, \& EspinosaGarcía, 1995). More specifically, Downs et al. (2009) reported that hypo-saline conditions can cause an oxidative stress response in both the host and the dinoflagellate, and that this can synergistically increase the damage to biomolecules via oxidative stress. In this sense, we can consider that as other environmental variables considered in this study, the decrease in salinity levels can cause a significant (negative) physiological effect on coral communities.

The high concentration of nutrients in the lagoon (BI and BII) is due to three factors: a) during the rainy season, the runoff from fertilizer on adjacent agricultural lands related to seasonal crops (mango, banana, corn, bean, tomatoes) (INEGI, 2009); b) the use of the lagoon as a receiving body for flows derived from a wastewater plant (primary treatment) located in a nearby residential area with an average daily effluent of $10 \mathrm{~L} / \mathrm{s}$ (CONAGUA, 2011), and c) the re-suspension of sediments with a high organic matter content generated by the tides and winds (Gaviño-Rodríguez et al., 2011). For example, during the rainy season, the increased continental runoff resulted in high nutrient concentrations in La Boquita coral community. During the October peak, $\mathrm{NH}_{4}^{+}, \mathrm{PO}_{4}{ }^{3-}$, and $\mathrm{SiO}_{2}$ concentrations were one order of magnitude higher than those reported for the central part of Santiago Bay (Olivos-Ortiz et al., 2008). The contribution of continental discharges and the alterations due to anthropogenic activities (Turner, Rabalais, \& Dortch, 2003), can be expected to lead to the eutrophication of the lagoon, along with the further exportation of nutrients to adjacent marine areas. This was evidenced by the stoichiometric relationship showing an excess of $\mathrm{PO}_{4}^{-3}$ and $\mathrm{SiO}_{2}$ and thus changes in the water column, with subsequent major changes in the structure of the coral reefs, which could have as a final result in loss of coverage, referred to below.

Increases in nutrient concentrations $(>5$ $\mu \mathrm{M} \mathrm{NO}{ }_{3}^{-}, 2.5 \mu \mathrm{M} \mathrm{PO}_{4}{ }^{3-}$ ) in coral reef communities have been significantly related to increases in the load of suspended material, which can promote algal growth and macroalgal abundances, as well as trapping sediments and thus followed by a sedimentation increase (Fabricius et al., 2013). Bioerosion has been related to low coral recruitment and ultimately to declining biodiversity due to high productivity and low light penetration, which affects water quality (Ferrier-Pagés, Gattuso, Dallot, \& Jaubert, 2000; Nordemar, Nyström, \& Dizon, 
2003; De'ath \& Fabricius, 2010; Le Grand \& Frabicius, 2011; Fabricius et al., 2013). Similarly, Vermeij et al. (2010) reported that for Caribbean coral Orbicella (cf. Montastraea) annularis, local nutrient enrichment promoted an overgrowth of turf algae (multi-species communities of small marine macrophytes), which reduced the coral fitness, because these algae affect the average effective photochemical efficiency of neighboring coral. In our monitoring, we were able to verify these effects in the part of enriched waters, particularly for the turbidity and abundance-of-algae indicators for the sampled months. It was possible to observe that the turbidity was significantly lower at the C1 station in relation to other stations, while the abundance of algae remained significantly higher. This increase in turbidity in this area of the reef had been previously reported for 2007 by Liñán-Cabello et al. (2008).

In the study area, the constant supply of eutrophicated water from the lagoon, evidenced by the high concentrations of DIN, P, and $\mathrm{Si}\left(10.3 \mu \mathrm{M} \mathrm{NO}_{2}^{-}+\mathrm{NO}_{3}^{-}, 2.2 \mu \mathrm{M} \mathrm{NH}_{4}^{+}\right.$, $3.7 \mu \mathrm{M} \mathrm{PO}_{4}{ }^{3-}$, and $19.2 \mu \mathrm{M} \mathrm{SiO}_{2}$ ), when compared with the reported values in the adjacent bay area $\left(4.2 \mu \mathrm{M} \mathrm{NO}_{2}{ }^{-}+\mathrm{NO}_{3}{ }^{-}, 0.2 \mu \mathrm{M} \mathrm{NH}_{4}{ }^{+}\right.$, $0.8 \mu \mathrm{M} \mathrm{PO}_{4}{ }^{3-}$, and $4.9 \mu \mathrm{M} \mathrm{SiO}_{2}$ ) (Olivos-Ortiz et al., 2008), can support high phytoplankton abundance (until $1.6 \times 10^{5}$ cells/L around CS) similar to values reported in Santiago bay locations far from continental runoffs, with values of $1.5 \times 10^{2}$ to $2.2 \times 10^{3}$ cells/L (Quijano-Scheggia et al., 2013). Together with dissolved solids in the water column, these blooms caused a shadow effect that negatively impacted the baseline requirements for zooxanthellae photosynthesis, with further negative effects on coral, such as decreased calcification, increased mucus production, coral bleaching, and even mortality (Walker \& Ormond, 1982; Telesnicki \& Goldberg, 1995; Anthony \& Fabricius, 2000). This scenario is consistent with our observations since in our various CoralWatch records, it was observed that the station $\mathrm{C} 1$ presented many specimens with colorations 1 and 2, and denoting paleness and poor health condition in hues $\mathrm{E}$ and $\mathrm{D}$, whereas in $\mathrm{C} 2$ and
C3 were observed more hues and colorations of 3, 4, 5 which could denote variety of hues and more zooxanthellae aggregation. According to the abundance of coral morphotypes in the three monitored months, it was possible to see that this abundance profile was maintained. In an assessment of the restored Bay of Carrizales, located $7 \mathrm{~km}$ from the study area, all four hues of the CoralWatch scale were found in the coral community. Likewise, changes were observed in hues of wild populations with respect to the time of year; organisms undergoing restoration were unchanged from their original hues ( $\mathrm{E}$ and B) (Liñán-Cabello et al., 2011).

In a study on La Boquita coral community during 2012, Laurel-Sandoval et al. (2013), who used Massive Sequencing Techniques for the amplification of $16 \mathrm{~S}$ rRNA coral tissue, identified a total of 28 phyla, 59 classes, 119 orders, 245 families, 600 genera and 24 bacterial species in the Pocillopora capitata coral in La Boquita and Carrizales coral communities. The sampling of these specimens was performed using the CoralWatch scale corresponding to morphotypes: partially bleached (hue 2), pale (hue 4), and normal (hue 6). Also, the presence of the genus Serratia was associated with mucus in both specimens from La Boquita, which was an indicator of bacterium anthropogenic pollution (Patterson et al., 2002). However, Laurel-Sandoval et al. (2013) reported that its greatest abundance was associated with morphotypes of partially bleached coral (hue 2), which along with hues 1 and 3, are most prevalent in species with the greatest intensity of coloration in La Boquita. The presence of Serratia in Carrizales also suggests that there is some anthropogenic influence in Carrizales, despite its location at $7 \mathrm{~km}$ away from areas of anthropogenic influence.

As shown by Wiedenmann et al. (2013), nitrogen enrichment can induce the replacement of phospholipids by sulpholipids in zooxanthellae. A recent study that assessed the impacts of nutrient enrichment on coral reefs concluded that, increased nutrient levels are linked to the appearance and severity of diseases in coral communities (Risk, 2014). An 
in vitro investigation by Dunn, Sammarco and LaFleur, (2012) showed that high concentrations of phosphorus have a beneficial effect on the morphological indicators associated with the growth of Acropora muricata. As previously reported for other coral species (Koop et al., 2001; Lirman \& Fong 2007), phosphate was shown to enhance coral growth by increasing zooxanthellae density, and thus photosynthetic production. However, Dunn et al. (2012) also found that in the presence of high phosphate concentrations, skeletal density decreased over time and was significantly lower in the high-phosphate treatment group. The observed effect may be due to phosphate binding to the calcifying surface, resulting in a porous and structurally weaker calcium carbonate/calcium phosphate skeleton.

In a recent study (Delgadillo-Nuño, LiñánCabello, Reyes-Gómez, \& Soriano-Santiago, 2014) comparing the microstructure of $P$. capitata from La Boquita reef from different regions exposed to the same depth and oceanic dynamics, a deterioration in the roughness patterns of the skeletal surface of La Boquita coral was noted, likely reflecting the fragility of the coral in terms of breakage and the difficulty of recovering from adverse conditions. Similar findings were obtained in the previously mentioned study of Pocillopora during a program of restoration (Islas-Peña, Liñán-Cabello, \& Torres-Orozco, 2013). In addition, in a report on different Pocillopora spp. communities along the Pacific Coast of Mexico, specimens from La Boquita, whether they were from surface areas or maximum depths, had higher chlorophyll $a$ concentrations, in both normal and pale-appearing coral than were seen in the same morphotypes collected at similar depths from localities not exposed to terrigenous effluent (Liñán-Cabello, Flores-Ramírez, Zacarias, Robelo, \& Lezama-Cervantes, 2006). Similarly, in a study conducted in the summer and winter of 2007, Liñán-Cabello et al., (2010a), compared chlorophyll $a$ concentrations and the density of zooxanthellae in $P$. capitata, exposed either to the Juluapan Lagoon effluent or located at a distance of $120 \mathrm{~m}$ away from the source of the effluent, no statistical differences in winter (dry season) were found; whereas during the rainy summer, when the nutrient supply was greater, significantly higher values were recorded in the effluent-exposed water compared to those of the distant area.

In their assessment of community assembly during the restoration process in La Boquita reef in 2010, Islas-Peña et al. (2013) observed that Pocillopora survival was affected by bioerosion effects attributed to invertebrates, such as the sponge Amphimedon texotli sp., which grows as tubes between coral branches and protrudes more prominently in dead coral and rocks. Abundant species of fish identified in that study included Chaetodon humeralis, Stegastes acapulcoensis, and Sufflamen verres. In our study, S. acapulcoensis, Thalassoma lucasanum, Holacanthus passer, and Microspathodon dorsalis were the most abundant species. According to López-Pérez et al. (2012), in their study of reef fish in Oaxaca, Mexico, S. acapulcoensis and T. lucasanum accounted for $59 \%$ of the population. A similar abundance (56\%) was reported by Galván-Villa, López-Uriarte and Arreola-Robles, (2011) in their analysis of Tenacatita Bay, Jalisco, Mexico. S. acapulcoensis and $M$. dorsalis are corallivorous (Galván-Villa et al., 2011) and were suggested by both authors to account, at least in part, for the observed adverse changes in the respective coral populations and therefore the loss of coral cover. In our study zone, about 270 meters from the coral community, there is fixed fishing gear (Daibo-Ami type) that operates continuously for nine months a year. This fishing gear can catch between 100-600 kg daily, with an abundance of species between seven and 32 (Espino-Barr, Jiménez-Quiroz, Granados-Montes de Oca, \& Garcia-Boa, 2006). This type of fishing gear is known for not discriminating with regard to fish size. Therefore, we consider this fishing gear to be a factor that impacts not only the abundance of species, but also the fish diversity of this coral community.

Our observations strongly point to fluctuations in and/or high levels of nutrients in La Boquita community, contributing to the 
high level of photosynthetic production and high zooxanthellae density, as well as the proliferation of algae-type grass in $\mathrm{C} 1$. These factors may have contributed to reduced coral calcification, leading to a reduced skeletal density, worsening bioerosion, and ultimately coverage loss (Bartley, Speirs, Ellis, \& Waters, 2012; Risk, 2014).

The main evidence for deterioration in $\mathrm{La}$ Boquita coral community is the loss of coverage. Liñán-Cabello et al. (2008) reported a 7 $\%$ decrease in 2007, an amount that according to our observations taken during the same sampling period, has now reached $17 \%$. The most dramatically affected area is near the connection between the channel and Juluapan lagoon ( $\mathrm{C} 1$ of the present study). Here, the status of the coral is poor, and the influence of nutrient-enriched waters and an increased sedimentary rate is the highest. Digital appendix 1 shows the transition zone between the slightly impacted coral, with signs of bleaching, and the area most strongly subjected to terrestrial runoff, where the coral is covered by sediments. According to Hallock (2012), these sediments do not initially negatively impact coral health, because the growth of bacteria and algae may stabilize the sediments and provide optimal conditions for the growth of coral-colonizing foraminifera.

Oxidative stress leads to bleaching and thus serves as a good indicator of the health of coral populations subjected to environmental changes (Lesser, 2006). However, both zooxanthellae and cnidarians have antioxidant defense systems that inhibit the formation of reactive oxygen species (ROS), which are produced during bleaching (Lesser \& Shick, 1989; Lesser, 1996). Newly published studies have shown an association between increased ROS production, including the one caused by an increase in ROS-producing units (algal cells), and nutrient-driven alterations in the lipid compositions of zooxanthellae membranes (Cunning \& Baker 2013; Wiedenmann et al., 2013).

However, there are also reports that suggest acclimatization to terrestrial runoff on the part of La Boquita coral community. It has been exposed to this runoff for the last 10 years, following the opening of the channel and thus the modification of the Juluapan Lagoon and Santiago Bay. In those studies, some of which involved in vitro experiments with La Boquita specimens, the responses of the host and its symbiont to changes in $\mathrm{pH}$, UV radiation, and temperature were investigated (Flores-Ramirez \& Liñán-Cabello, 2007; Liñán-Cabello et al., 2008; 2010b; Soriano-Santiago, Liñán-Cabello, Delgadillo-Nuño, Ortega-Ortiz, \& CuevasVenegas, 2013). The results provided evidence of a synchronous, short response time on the part of antioxidant enzyme activity in coral tissue, specifically by the zooxanthellae, which reduced the amount of cell damage.

The main anthropogenic disturbances from areas adjacent to La Boquita reef are wastewater discharges into the lagoon, tourist developments in the coastal zone, deforestation and erosion resulting from inappropriate development, and the nutrient runoff from agricultural lands around the lagoon. All these significantly contributed to the nutrient-enriched waters of the lagoon, especially in summer, with negative effects on the coral community. Because the lagoon remains in constant communication with Santiago Bay throughout the year, and despite potential physiological adjustments by the coral community, the shading effects, the large sediment load, and the high primary productivity; may act synergistically to potentiate the effects of the bioerosion and burial of the coral, which results in a major loss of coverage.

We identified the need for preventive diagnostic studies to determine the state of stress in coastal coral communities from a multi-disciplinary perspective, including the practice of population assessments, such as the presence of certain species indicating an imbalance in the ecosystem; the use of biochemical/molecular tracers; and the importance of nutrients such as phosphate, nitrogen and their relationship to the abnormal growth of coral. Future studies must incorporate multiple visions to improve our understanding to identify methods and sites with higher potential for success in terms of restoration actions. Our findings highlight the 
need of appropriate coral reefs conservation policies and integrated coastal development management for the Mexican Pacific Coast.

\section{ACKNOWLEDGMENTS}

It is a pleasure to thank my past students and colleagues who have participated in and contributed to the various parts of this research. We are also grateful to the editor Wendy Ran for reviewing the language. We appreciate the thorough and thoughtful comments of two anonymous reviewers.

\section{RESUMEN}

Dependiendo de la ubicación geográfica, la profundidad, y la proximidad a zonas de recreo, algunos arrecifes de coral están bajo estrés por factores que incluyen la sedimentación, la fragmentación, la sobrepesca y el turismo. En la presente investigación, se estudian los diferentes atributos de calidad de agua de la Laguna Juluapan e indicadores del estatus de la comunidad coralina La Boquita. Durante 2011 (12 meses de muestreo), seis estaciones de monitoreo fueron establecidas dentro de la laguna de Juluapan, a fin de observar el gradiente de distribución de los parámetros fisicoquímicos: tres estaciones en la parte interna ó B1, (S4 a S6), y tres en la parte más externa, ó B2 (S1 a S3); una estación control (CS) fue ubicada en la zona coralina cercana a la comunicación con la Laguna de Juluapan, fueron determinados nutrientes inorgánicos disueltos y contenido de carbono celular. Adicionalmente se realizó el monitoreo de tres de los ocho cabezales coralinos que conforman esta comunidad. El primero de ellos fue localizado en la cercanía de la intercomunicación con la Laguna Juluapan (C1), el segundo en la región intermedia respecto a la proximidad de dicho cuerpo lagunar (C2), y el tercero totalmente alejado respeto a la intercomunicación (C3). En cada estación fueron colocadas, tres líneas de transectos de intersección (LIT) de $30 \mathrm{~m}$ de longitud de forma perpendicular al perfil de la costa, a partir de ello, fueron evaluados diversos parámetros de la condición coralina , cubriendo una área de $60 \mathrm{~m}^{2}$ en cada transecto $\left(180 \mathrm{~m}^{2}\right.$ por estación). En cada área de transecto fue evaluada la turbidez, evidencias de daños por pesca, daños por sedimentación, cobertura de algas, abundancia de peces, tasa de sedimentación, además de obtenerse registros de la salud coralina usando como indicador la tarjeta CoralWatch in situ, a partir de tomas fotográficas y videos. Considerando los diferentes indicadores del estatus de la comunidad coralina estudiada, nosotros pudimos reconocer un estado general de deterioro, reflejado en la pérdida del $17 \%$ de la cobertura de coral. Las principales alteraciones antropogénicas en las zonas adyacentes al arrecife La Boquita corresponde a descargas de aguas residuales en la laguna, desarrollos turísticos en la zona costera, la deforestación y efecto erosivo asociado al desarrollo urbano inadecuado, así como el escurrimiento de nutrientes de tierras agrícolas alrededor de la laguna. Estos factores contribuyen de manera significativa al enriquecimiento de nutrientes a la laguna, sobre todo en verano, con efectos negativos sobre la comunidad de coral. La exposición continua a estos factores, junto con la falta de control sobre otros componentes antropogénicos, promueve la existencia de un estado de estrés crónico en la comunidad coralina estudiada. Nuestros resultados destacan la necesidad de implementar políticas apropiadas de conservación para los arrecifes coralinos de la costa del Pacífico mexicano.

Palabras clave: ambientes coralinos, pérdida de cobertura, impactos antropogénicos, bioerosión, eutroficación, Pocillopora.

\section{REFERENCES}

Adey, W. H. (1998). Review-coral reefs: algal structured and mediated ecosystems in shallow, turbulent, alkaline waters. Journal of Phycology, 34, 393-406.

Anthony, K. R., \& Fabricius, K. E. (2000). Shifting roles of heterotrophy and autotrophy in coral energetics under varying turbidity. Journal of Experimental Marine Biology and Ecology, 252, 221-253.

Ban, S. S., Graham, N. A., \& Connolly, S. R. (2014). Evidence for multiple stressor interactions and effects on coral reefs. Global Change Biology, 20, 681-697.

Bartley, R., Speirs, W. J., Ellis, T. W., \& Waters, D. K. (2012). A review of sediment and nutrient concentration data from Australia for use in catchment water quality models. Marine Pollution Bulletin, 65, 101-116.

Buddemeier, R., Kleypas, J., \& Aronson, R. (2004). Coral Reefs and Global Climate Change: Potential Contributions of Climate Change to Stresses on Coral Reef Ecosystems. Arlington, Virginia: Pew Center on Global Climate Change.

Cesar, H., Burke, L., \& Pet-Soede, L. (2003). The economics of worldwide coral reef degradation. 6Arnhem, The Netherlands: Environmental Economics Consulting (CEEC).

CONAGUA (2011). Estadísticas del agua en México, edición 2011. México: CONAGUA.

Costa, O. S., Nimmo, M., \& Attrill, M. J. (2008). Coastal nutrification in Brazil: a review of the role of nutrient excess on coral reef demise. Journal of South American Earth Sciences, 25, 257-270.

Crabbe, M. J. C., Walker, E. L., \& Stephenson, D. B. (2008). The impact of weather and climate extremes on coral 
growth. Climate Extremes and Society (pp. 165-188). Cambridge, UK: Cambridge University Press.

Crain, C. M., Kroeker, K., \& Halpern, B. S. (2008) Interactive and cumulative effects of multiple human stressors in marine systems. Ecology Letters, 11(12), 1304-1315.

Cunning, R., \& Baker, A. C. (2013). Excess algal symbionts increase the susceptibility of reef corals to bleaching. Nature Climate Change, 3, 259-262.

De'ath, G., \& Fabricius, K. (2010). Water quality as a regional driver of coral biodiversity and macroalgae on the Great Barrier Reef. Ecological Applications, $20,840-850$.

Delgado, O., \& Lapointe, B. E. (1994). Nutrient-limited productivity of calcareous versus fleshy macroalgae in a eutrophic, carbonate-rich tropical marine environment. Coral Reefs, 13, 151-159.

Delgadillo-Nuño, M. A., Liñán-Cabello, M. A., ReyesGómez, J., \& Soriano-Santiago, O. (2014). Respuestas al estrés de $\mathrm{pH}$ en el coral petreo Pocillopora capitata (Anthozoa: Scleractinia). Revista de Biología Marina y Oceanografia, 49, 449-459.

Downs, C. A., Kramarsky-Winter, E., Woodley, C. M., Downs, A., Winters, G., Loya, Y., \& Ostrander, G. K. (2009). Cellular pathology and histopathology of hypo-salinity exposure on the coral Stylophora pistillata. Science of the Total Environment, 407, 4838-4851.

Dunn, J. G., Sammarco, P. W., \& LaFleur, G. (2012). Effects of phosphate on growth and skeletal density in the scleractinian coral Acropora muricata: A controlled experimental approach. Journal of Experimental Marine Biology and Ecology, 411, 34-44.

Espino-Barr, E., Jiménez-Quiroz, M. C., Granados-Montes de Oca, N., \& Garcia-Boa, A. (2006). Análisis de la captura de la almadraba de Miramar, Manzanillo, Colima (1993-1998). In M. C. Jiménez-Quiroz y E. Espino-Barr (Eds.), Los recursos pesqueros y acuícolas de Jalisco, Colima y Michoacán (pp. 525-538). México: INP, SAGARPA.

Fabricius, K. E. (2005). Effects of terrestrial runoff on the ecology of corals and coral reefs: review and synthesis. Marine Pollution Bulletin, 50, 125-146.

Fabricius, K. E., De'ath, G., Humphrey, C., Zagorskis, I., \& Schaffelke, B. (2013). Intra-annual variation in turbidity in response to terrestrial runoff on nearshore coral reefs of the Great Barrier Reef. Estuarine, Coastal and Shelf Science, 116, 57-65.

Falkowski, P. G., Jokiel, P. L., \& Kinzie, R. A. (1990). Irradiance and corals. Ecosystems of the World, $25,89-107$
Ferrier-Pagés, C., Gattuso, J. P., Dallot, S., \& Jaubert, J. (2000). Effect of nutrient enrichment on growth and photosynthesis of the zooxanthellate coral Stylophora pistillata. Coral Reefs, 19, 103-113.

Flores-Ramírez, L. A., \& Liñán-Cabello, M. A. (2007). Relationships among thermal stress, bleaching and oxidative damage in the hermatypic coral, Pocillopora capitata. Comparative Biochemistry and Physiology Part C: Toxicology \& Pharmacology, 146, 194-202.

Galván-Villa, C. M., López-Uriarte, E., \& Arreola-Robles, J. L. (2011). Diversidad, estructura y variación temporal del ensamble de peces asociados al arrecife coralino de playa Mora, bahía de Tenacatita, México. Hidrobiológica, 21, 135-146.

Gaviño-Rodríguez, J. H., Reyes-Herrera, E. A., ObesoNieblas, M., Quijano-Scheggia, S., García-García, M., Olivos-Ortiz, A., Patiño-Barragán, M., \& GaliciaPérez, M. A. (2011). Aspectos hidrodinámicos de la Laguna de Juluapan, Colima. In 'Congreso Nacional de Ciencia y Tecnología del Mar’, 2011, Guaymas, Sonora.

Grasshoff, K., Ehrhardt, M., \& Kremling, K. (1999). Methods of Seawater Analysis (3nd edn, 419 pp.) Germany: Wiley-VCH.

Hallock, P. (2012). The FORAM Index revisited: usefulness, challenges and limitations. Proceedings International Coral Reef Symposium, Cairns, Australia.

Hilmi, N., Safa, A., \& Reynaud, S. (2012). Coral Reefs and Tourism in Egypt's Red Sea. Topics in Middle Eastern and North African Economies, electronic journal, Volume 14, Middle East Economic Association and Loyola University Chicago, September, 2012, http:// www.luc.edu/orgs/meea/

Hill, J., \& Wilkinson, C. (2004). Methods for ecological monitoring of coral reefs. Townsville: Australian Institute of Marine Science.

Hillebrand, H., Dürselen, C. D., Kirschtel, D., Pollingher, U., \& Zohary, T. (1999). Biovolume calculation for pelagic and benthic microalgae. Journal of Phycology, 35, 403-424.

Instituto Nacional de Estadística y Geografía INEGI. (2009). Prontuario de información geográfica municipal de los Estados Unidos Mexicanos. Clave Geoestadística 06007.

Islas-Peña, T., Liñán-Cabello, M. A., \& Torres-Orozco, E. (2013). Evaluation of two techniques for restoration of Pocillopora spp.: Early Effects of Species and Marine Environment. In M. A. Liñán-Cabello (Ed.), Corals: Classification, Habitat and Ecological Significance (pp.133-152) New York: Nova Publisher Science. 
Justic, D., Rabalais, N. N., Turner, R. E., \& Dortch, Q. (1995). Changes in nutrient structure of river-dominated coastal waters: stoichiometric nutrient balance and its consequences. Estuarine, Coastal and Shelf Science, 40(3), 339-356.

Koop, K., Booth, D., Broadbent, A., Brodie, J., Bucher, D., Capone, D., \& Yellowlees, D. (2001). ENCORE: the effect of nutrient enrichment on coral reefs. Synthesis of results and conclusions. Marine Pollution Bulletin, $42,91-120$.

Larkum, A. W. D., \& Koop, K. (1997). ENCORE, algal productivity and possible paradigm shifts. In Proceedings 8th International Coral Reef Symposium, $1,881-884$

Laurel-Sandoval, M. A. M., Soto, R. S. A., Liñán-Cabello, M. A., Rodríguez-Sala, B., Gómez, G., \& Dinsdale, E. (2013). Caracterización de la comunidad microbiana del coral Pocillopora capitata en las comunidades arrecifales de Manzanillo, Colima. 7mo Congreso Mexicano \& ler Congreso Panamericano de Arrecifes Coralinos. Octubre 2013, Mérida Yuc, México. http://redoctober.sisal.unam.mx/1CPAC/Panamerican Coral Reef Congress/Documentos Documents_files/Programa-Resumenes7CM1CPAC.pdf) revisado 20 sep 2015.

Le Grand, H. M., \& Fabricius, K. E. (2011). Relationship of internal macrobioeroder densities in living massive Porites to turbidity and chlorophyll on the Australian Great Barrier Reef. Coral Reefs, 30(1), 97-107.

Lesser, M. P. (1996). Elevated temperatures and ultraviolet radiation cause oxidative stress and inhibit photosynthesis in symbiotic dinoflagellates. Limnology and Oceanography, 41, 271-283.

Lesser, M. P. (2006). Benthic-pelagic coupling on coral reefs: feeding and growth of Caribbean sponges. Journal of Experimental Marine Biology and Ecology, 328(2), 277-288.

Lesser, M. P., \& Shick, J. M. (1989). Effects of irradiance and ultraviolet radiation on photoadaptation in the zooxanthellae of Aiptasia pallida: primary production, photoinhibition, and enzymic defenses against oxygen toxicity. Marine Biology, 102, 243-255.

Liñán-Cabello, M. A., Flores-Ramírez, L. A., Cobo-Díaz, J. F., Zenteno-Savin, T., Olguín-Monroy, N. O., OlivosOrtiz, A., \& Tintos-Gómez, A. (2010b). Response to short term ultraviolet stress in the reef-building coral Pocillopora capitata (Anthozoa: Scleractinia). Revista de Biologia Tropical, 58(1), 103-118.

Liñán-Cabello, M. A., Flores-Ramírez, L. A., LaurelSandoval, M. A., Mendoza, E. G., Santiago, O. S., \& Delgadillo-Nuño, M. A. (2011). Acclimation in Pocillopora spp. during a coral restoration program in Carrizales Bay, Colima, Mexico. Marine and Freshwater Behaviour and Physiology, 44(1), 61-72.
Liñán-Cabello, M. A., Flores-Ramírez, L., Zacarias, J., Robelo, O., \& Lezama-Cervantes, C. (2006). Correlation of chlorophyll $a$ and total carotenoid concentrations with coral bleaching from locations on the Pacific coast of Mexico. Marine and Freshwater Behaviour and Physiology, 39(4), 279-291.

Liñán-Cabello, M. A., Flores-Ramírez, L. A., Zenteno-Savin, T., Olguín-Monroy, N. O., SosaAvalos, R., Patiño-Barragan, M., \& Olivos-Ortiz, A. (2010a). Seasonal changes of antioxidant and oxidative parameters in the coral Pocillopora capitata on the Pacific coast of Mexico. Marine Ecology, 31, 407-417.

Liñán-Cabello, M. A., Hernández-Medina, D., FloriánÁlvarez, P., \& Mena-Herrera, A. (2008). Estado actual del arrecife coralino 'La Boquita', Colima. Iridia, 5, 10-23.

Lirman, D., \& Fong, P. (2007). Is proximity to land-based sources of coral stressors an appropriate measure of risk to coral reefs? An example from the Florida Reef Tract. Marine Pollution Bulletin, 54, 779-791.

López-Pérez, R. A., Calderón-Aguilera, L. E., Reyes-Bonilla, H., Carriquiry, J. D., Medina-Rosas, P., Cupul-Magaña, A. L., \& Luna-Salguero, B. M. (2012). Coral communities and reefs from Guerrero, southern Mexican Pacific. Marine Ecology, 33, 407-416.

Maina, J., McClanahan, T. R., Venus, V., Ateweberhan, M., \& Madin, J. (2011). Global gradients of coral exposure to environmental stresses and implications for local management. PLoS One, 6(8), e23064.

Marshall, N. J., Kleine, D. A., \& Dean, A. J. (2012). Cora1Watch: education, monitoring, and sustainability through citizen science. Frontiers in Ecology and the Environment, 10, 332-334.

Martínez, F., Pardo, J. P., Flores-Herrera, O., \& EspinosaGarcía, M. T. (1995). The effect of osmolarity on human placental mitochondria function. The International Journal of Biochemistry \& Cell Biology, 27, 795-803.

Menden-Deuer, S., \& Lessard, E. J. (2000). Carbon to volume relationships for dinoflagellates, diatoms, and other protist plankton. Limnology and Oceanography, 45, 569-579.

Micheli, F., Saenz-Arroyo, A., Greenley, A., Vázquez, L., Espinoza Montes, J. A., Rossetto, M., \& De Leo, G. A. (2012). Evidence that marine reserves enhance resilience to climatic impacts. PloS one, 7(7), doi:10.1371/journal.pone. 0040832

Moyes, C. D., Moon, T. W., \& Ballantyne, J. S. (1986). Osmotic effects on amino acid oxidation in skate liver mitochondria. Journal of Experimental Biology, 125, 181-195. 
Nordemar, I., Nyström, M., \& Dizon, R. (2003). Effects of elevated seawater temperature and nitrate enrichment on the branching coral Porites cylindrica in the absence of particulate food. Marine Biology, $142,669-677$.

Olivos-Ortiz, A., Sosa-Avalos, R., Torres-Orozco, E., Silva-Iñiguez, L., Galicia-Pérez, M. A, \& GaviñoRodríguez, E. (2008). Influencia de las descargas de agua continental en la concentración de nutrientes en las Bahías de Santiago y Manzanillo, Colima. Iridia, 5, 6-15.

Patterson, K. L., Porter, J. W., Ritchie, K. B., Polson, S. W., Mueller, E., Peters, E. C., ... \& Smith, G. W. (2002). The etiology of white pox, a lethal disease of the Caribbean elkhorn coral, Acropora palmata. Proceedings of the National Academy of Sciences, 99, 8725-8730

Quijano-Scheggia, S., Olivos-Ortiz, A., Rivera-Vilarelle, M., Gaviño-Rodríguez, J., Álvarez, C., \& SosaAvalos, R. (2013). Cuatro años de monitoreo de fitoplancton en las Bahías de Manzanillo y Santiago. Segundo Congreso Sociedad Mexicana de Florecimientos Algales Nocivos. Universidad de Colima, Mazanillo, Colima.

Risk, M. J. (2014). Assessing the effects of sediments and nutrients on coral reefs. Current Opinion in Environmental Sustainability, 7, 108-117.

Rivera-Vilarelle, M. (2011). Caracterización del género Pseudo-nitzschia en las bahías de Manzani1lo, Col. México (Master Thesis). Universidad de Colima, Mexico.

Servicio Meteorológico Nacional SMN. (2011). Coordinación general de Ciclones Tropicales. Boletín informativo. smn.cna.gob.mx/ciclones/tempo2011/pacifico/ Jova-p11.pdf

Siebeck, U. E., Marshall, N. J., Klüter, A., \& Hoegh-Guldberg, O. (2006). Monitoring coral bleaching using a colour reference card. Coral Reefs, 25, 453-460.

Soriano-Santiago, O. S., Liñán-Cabello, M. A., DelgadilloNuño, M. A., Ortega-Ortiz, C., \& Cuevas-Venegas, S. (2013). Physiological responses to oxidative stress associated with $\mathrm{pH}$ variations in host tissue and zooxanthellae of hermatypic coral Pocillopora capitata. Marine and Freshwater Behaviour and Physiology, 46, 275-286.
Spalding, M., Ravilious, C., \& Green, E. P. (2001). World atlas of coral reefs. Prepared at the UNEP Word Conservation Monitoring Center University of California Press.

Strickland, J. D. H., \& Parsons, T. R. (1972). Determination of reactive silicate. A Practical Handbook of Seawater Analysis, 65-70.

Telesnicki, G. J., \& Goldberg, W. M. (1995). Effects of turbidity on the photosynthesis and respiration of two south Florida reef coral species. Bulletin of Marine Science, 57, 527-539.

Throndsen, J. (1995). Estimating cell numbers. In G. M. Hallegraeff, D. M. Anderson, A. D. Cembella (Eds.). Manual on Harmful Marine Microalgae (Vol. 33-80, pp. 63-80). Paris: IOC Manual and Guides UNESCO.

Turner, R. E., Rabalais, N. N., \& Dortch, Q. (2003). Future aquatic nutrient limitations. Marine Pollution Bulletin, 46, 1032-1034.

Titlyanov, E. A., Tsukahara, J., Titlyanova, T. V., Leletkin, V. A., Van Woesik, R., \& Yamazato, K. (2000). Zooxanthellae population density and physiological state of the coral Stylophora pistillata during starvation and osmotic hock. Symbiosis, 28, 303-322.

Utermöhl, V. H. (1931). Neue Wege in der quantitativen Erfassung des Planktons. Verh. Internationalen Vereinigung fur Theoretische und Angewandte Limnologie, $5,567-596$

Vermeij, M. J., Van Moorselaar, I., Engelhard, S., Hörnlein, C., Vonk, S. M., \& Visser, P. M. (2010). The effects of nutrient enrichment and herbivore abundance on the ability of turf algae to overgrow coral in the Caribbean. PLoS One, 5, e14312.

Walker, D. I., \& Ormond, R. F. G. (1982). Coral death from sewage and phosphate pollution at Aqaba, Red Sea. Marine Pollution Bulletin, 13, 21-25.

Wiedenmann, J., D’Angelo, C., Smith, E. G., Hunt, A. N., Legiret, F. E., Postle, A. D., \& Achterberg, E. P. (2013). Nutrient enrichment can increase the susceptibility of reef corals to bleaching. Nature Climate Change, 3, 160-164.

Zar, J. H. (1994). Biostatistical analysis. Englewood Cliffs, New Jersey: Prentice-Hall, Inc. 